\title{
Highlights and sidelights of early Biology on Helgoland
}

\author{
E. Florey \\ Faculty of Biology, University of Konstanz; P.O. Box 5560, D-78434 Konstanz, Germany
}

\section{INTRODUCTION}

Great Britain ceded the island of Helgoland to Germany in 1890, and two years later the island came under Prussian administration. In that same year of 1892, the Biologische Anstalt Helgoland was established. But German biologists had come to this island before there was a laboratory available to them. In fact, long before the founding of the Biologische Anstalt, a sojourn on Helgoland, undertaken privately and with improvised facilities, was of decisive importance for the development of the new Zoology and new Botany that was created during the nineteenth century. Many of the key figures who were to revolutionize Biology, received on this island the inspiration that determined their later scientific accomplishments; among these were Ferdinand Cohn, Anton Dohrn, Hans Driesch, Christian Gottfried Ehrenberg, Ernst Haeckel, Albert Koelliker, Rudolf Leuckart, Johannes Müller, Carl Nägeli, Nathanael Pringsheim, and Rudolph Wagner. Their personal experiences and their accomplishments on this island of Helgoland are the subject of the following report, which also illustrates the interdependence of science and politics."

The history of science is intimately bound up with cultural and political history. Helgoland is not only an island of interest to scientists, it has also been of political and military interest - and its availability to biologists has had much to do with its political history.

Until 1807 Helgoland was under Danish administration, as was much of the northern part of Germany, especially the region now represented by the state of SchleswigHolstein (see Fig. 1). By that time, Napoleon had already conquered much of Europe. France ruled northern Germany, and its sphere of political dominance included Prussia. The so called continental system ("Kontinentalsperre" in German), put into operation by the French government, closed the European ports to British trade. England was forced to counter this economic blockade. Although the French fleet had been severely decimated in the battle of Trafalgar, it remained sufficiently strong to enforce the blockade. When, in 1807, the Danish refused to form an alliance with Britain, an

\footnotetext{
- Accounts of political and social history (unless part of common knowledge), and information concerning individual biographies are based on the literature listed at the end of this paper. I translated passages quoted from letters and literature into English; the original language is, of course, German. The German original is given in the Notes. All translated texts are from books and papers cited in the reference list at the end
} 


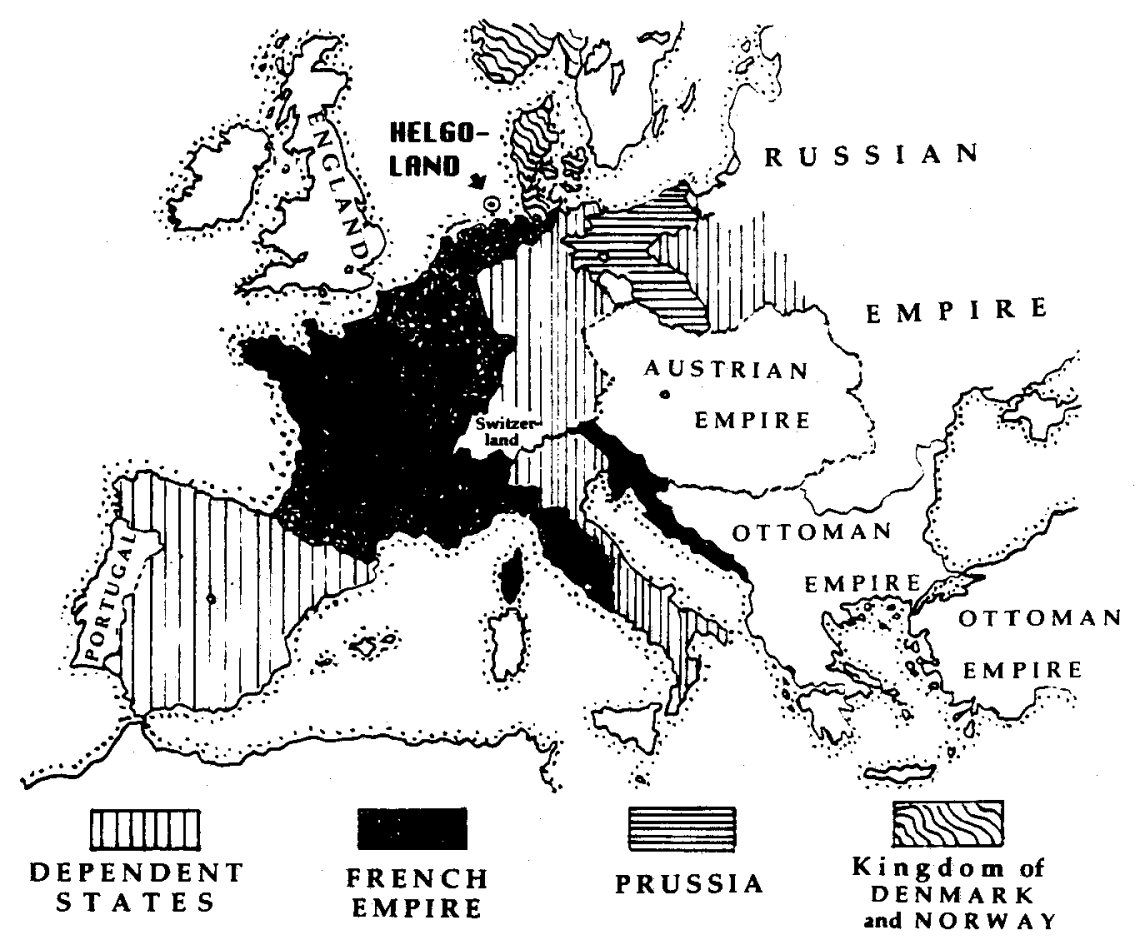

Fig. 1. Sketch of the political map of Europa around 1810, when Helgoland was occupied by Britain, and most of Europe was dominated by France. The duchies of Schleswig and Holstein represent the southern part of Denmark

English expeditionary naval force bombarded Copenhagen and forced Denmark to surrender its fleet, thus removing it from potential use against Britain in case of a possible Danish-French alliance. An English naval force occupied Helgoland and the island then became an all-important trading post and a naval stronghold from whence British warships could accompany and protect trading vessels that brought British goods from Helgoland to the German coast. Large ships delivered merchandise to Helgoland, where it was transferred to smaller vessels that could move closer to the German coast for clandestine unloading. Numerous British and German trading companies established offices on the island, and as many as 150 sailing ships arrived each day in the island's protected waters. This economic boom lasted only a few years - until the fall of Napoleon in 1813. In 1814 Great Britain came legally into possession of the island, and in 1815, the Congress of Vienna reorganised Europe completely (Fig. 2).

The new European trade agreements now obviated a strong naval presence on the island, and Helgoland was no longer needed as a commercial trading centre. Its economy declined rapidly, the foreigners left, and the inhabitants had to beg Britain for economic assistance. It was an enterprising ship's carpenter, Jacob Andresen Siemens, who hit upon the idea of transforming Helgoland into a fashionable sea resort, similar to the very successful new bathing towns on the mainland, like Heiligendamm on the Baltic Sea (begun in 1793), or those on the islands of Norderney and Föhr. It took many years until 


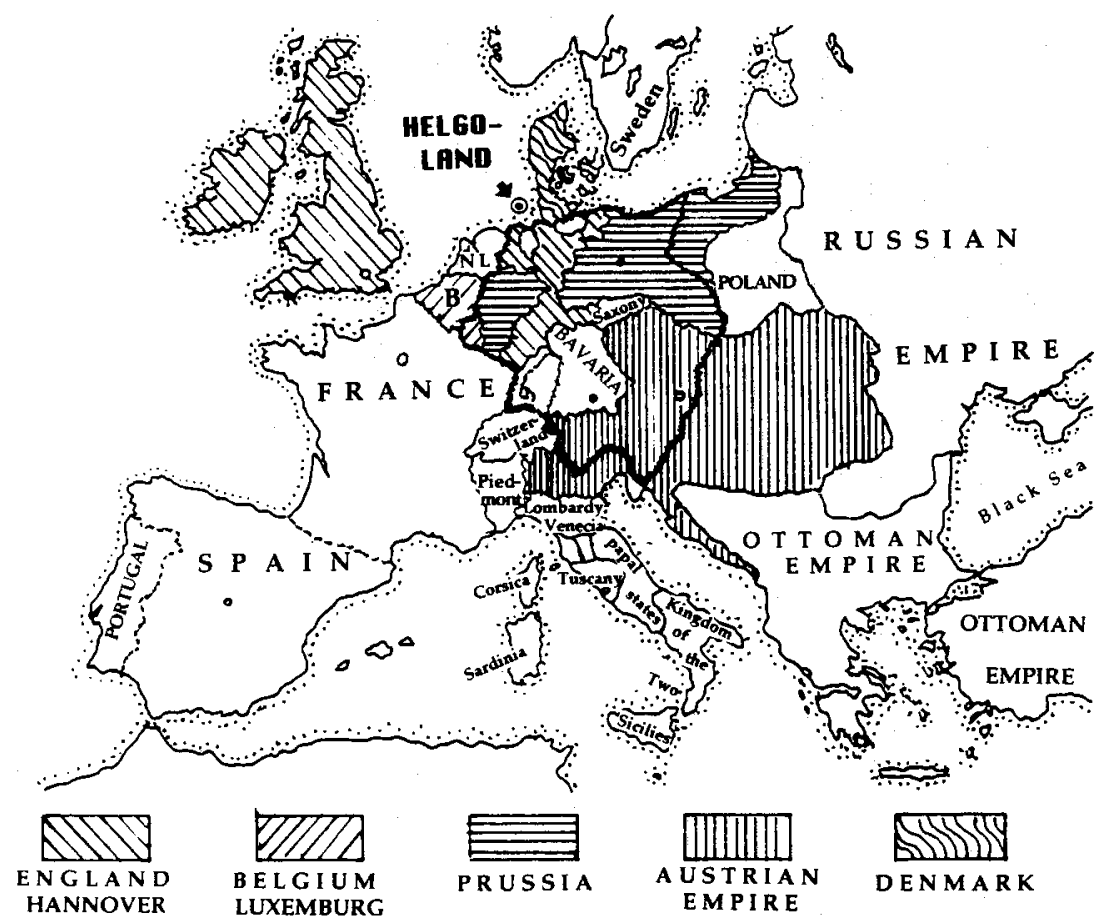

Fig. 2. Europe after the fall of Napoleon and after the Congress of Vienna (1815). The heavy line marks the boundary of the German Confederation

the venture became a reality, but from the late twenties on. Helgoland captured the new holiday trade, and the island became a fashionable resort (Fig. 3). It now became possible to rent rooms or cottages, a regular commercial boat service was established - and the local fishermen found employment, rowing guests from the incoming sailing boats and steamboats to the shore, and from the main island, the Rock, to the Dunes where a bathing-beach was established. The township organized nightly illuminations of the cliffs and their caves by "Bengal lights" which could be viewed from rowing-boats manned by local fishermen (Fig. 4). A Conversation House ( Conversationsh a us) was built where guests could socialize and be entertained by musicians (Fig. 5). There were dancehalls where the local girls in their native costumes were attractive partners for the male guests of the island.

Helgoland became an attraction not only for those seeking relaxation or holiday fun, but also for naturalists. In the beginning, it was mainly the algae that caught the attention of amateur and professional botanists alike. Helgoland, after all, represents the only rocky coast in all Germany, and the algae, when properly dried and mounted, made most attractive displays that were traded among amateur botanists, like postage stamps among philatelists (see Mollenhauer \& Lüning, 1988). It did not take long before the scientists took note of the opportunities offered by the island - and this is how the scientific history of Helgoland began. 


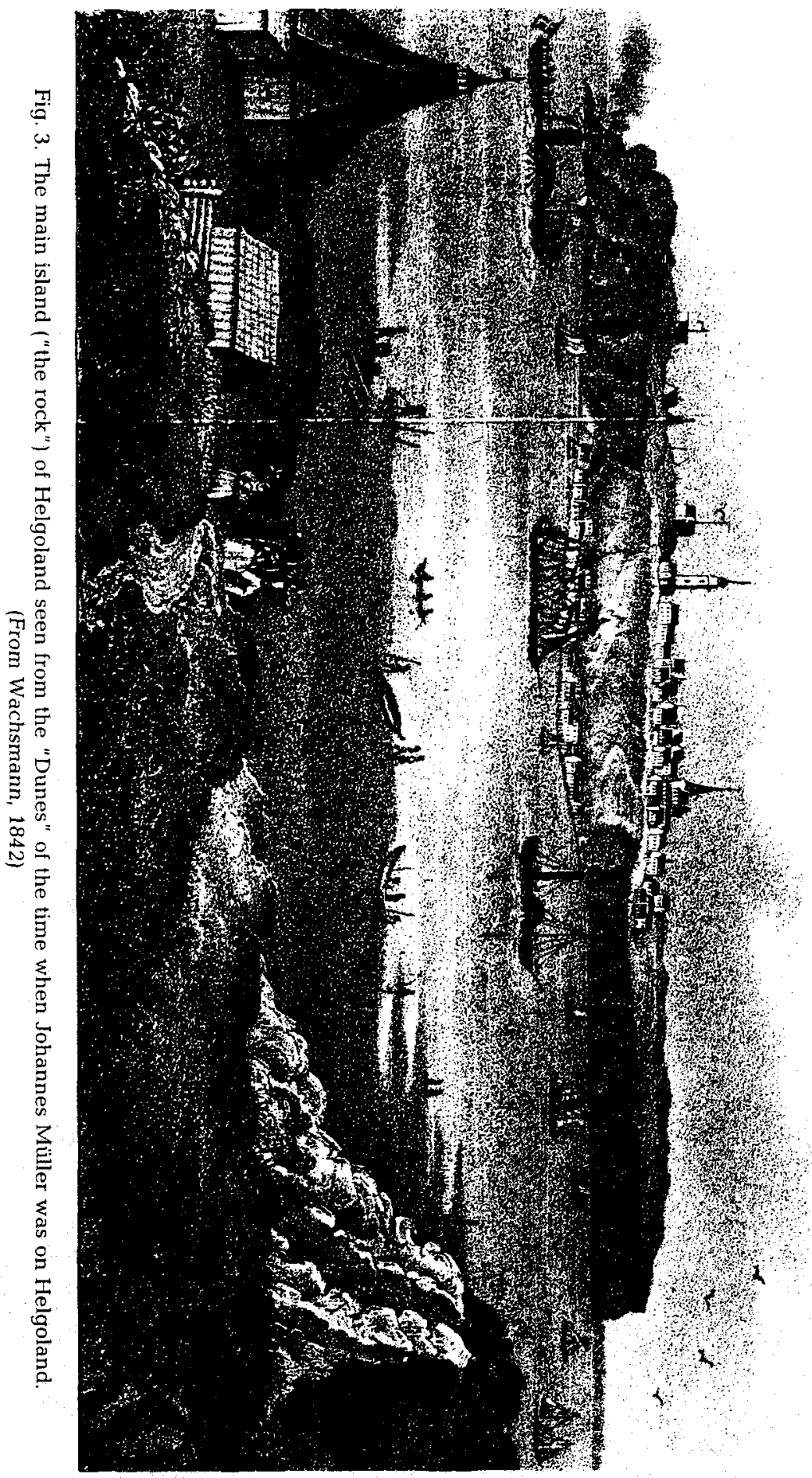




\section{JOHANNES MÜLLER (1801-1858)}

In 1833, Johannes Müller, who was to become the Nestor of German Zoology, was appointed Professor of Anatomy and Physiology at the Medical School of Berlin University. His interests were far-ranging, but what occupied him most was Comparative Anatomy and Systematic Zoology. He embarked on an extensive study of the Cyclostomes and demonstrated that detailed knowledge of the internal structure and organisation - and not only knowledge of the external features of animals - was a prerequisite of a true assessment of the taxonomic position of animal species.

Müller recognised the immense variety of animal life in the oceans, and turned more and more to marine forms - both vertebrate and invertebrate. At first he relied on museum specimens and on preserved animals his friends and colleagues sent him. But more and more, whenever time permitted (generally during the interval between semesters) he travelled to the sea coast, to obtain specimens from the fish market and from privately-hired fishermen. Müller's interest in living marine organisms was undoubtedly stimulated by the reports and exploits of his colleague Christian Gottfried Ehrenberg who, as we shall see, was among the first biologists to come to Helgoland (in 1835), and

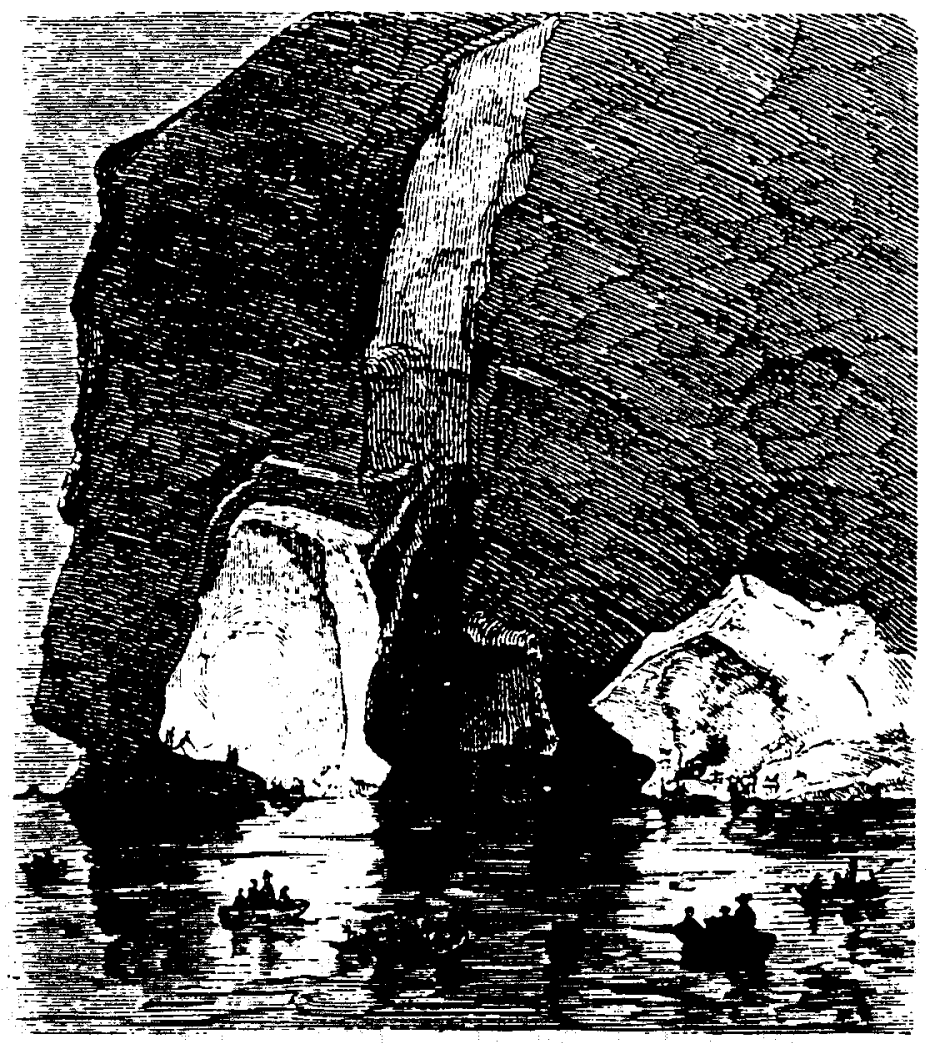

Fig. 4. Spectators in rowboats admire the caves of the "Rock" illuminated at night by "bengal lights" (from Reinhardt, 1856) 


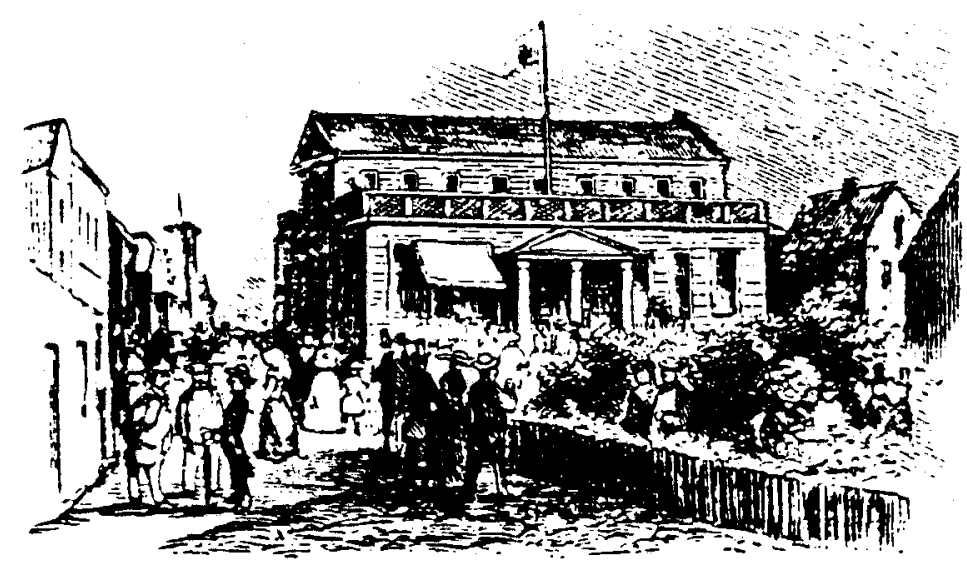

Fig. 5. The conversation house on Helgoland (from Reinhardt, 1856)

who had pioneered the use of the microscope in the exploration of minute aquatic animals.

Müller's enthusiasm and his successes were infectious. Several of his students followed his example and either went to the sea shore on their own, as did, for instance, the latterly famous Albert Koelliker who, in 1840, spent a working holiday on the island of Helgoland; others had the good fortune to be in Müller's company during his marine journeys, as was Ernst Haeckel to whom, in 1854, Müller introduced plankton fishing again on the island of Helgoland.

In 1838, Müller was on the mediterranean coast of France (in Marseille), and from there went to Genoa, in pursuit of elasmobranchs. In 1840 he travelled to Trieste to study echinoderms. But his duties in Berlin, especially after he had become Dean of the Medical Faculty, did not allow him time to travel - until 1845, when he managed to get away for about a month. He selected Helgoland, which then could be reached in three days - not by the slow land route, but conveniently by boat. A brief journey from Berlin to Potsdam conveyed the travellers to the river Havel from whence a comfortable boat took them overnight from Potsdam to Hamburg. Passengers slept in numbered lounge chairs. Arrival at the Jungfernstieg in Hamburg was at 9 in the morning, departure for the long boat-trip to Helgoland via Cuxhaven was early next day at 6 . Evidently the last sea journey took all day, and many were seasick.

Incidentally, the ticket from Berlin to Hamburg cost $81 / 2$ Thaler, that from Hamburg to Helgoland another 4 Thaler (round-trip 6 Thaler). By comparison, Müller's apartment in Berlin cost him 360 Thaler a year; he earned about 500 Thaler during summer and 1000 Thaler during winter semesters, in lecture fees.

Müller's letters to his wife contain many tidbits about Helgoland and its inhabitants. "The Helgolanders are rather idle people. ... They are excluded from major fishing because there is no harbour in which to keep ships during the winter ... Their boats are of no other use than to be rowed to the Dune. The race of people is rather pretty; one speaks German and eats German. In the afternoon, everybody crowds in on the Conversation House; one is very unceremonious ..." In his letter of August 30th he writes: 
"Everything here becomes an event, the arrival of a steamer or the passing of a faraway sailing ship. The whole day the beach is crowded with people who take boat-rides to go bathing or for pleasure, or who drink coffee near the breakers." 2

Müller had taken three students with him and much enjoyed their company. He was surprised that no-one asked to see their passports. Europe, by then, had been totally reorganised since the famous Congress of Vienna took place in 1815. There was now a new political union, the German Confederation (Deutscher Bund), headed by no less than 35 monarchs, among them the Emperor of Austria and the kings of Great Britain (as King of Hannover), Denmark (as Duke of Holstein), the Netherlands (as King of Luxemburg), Saxony, Prussia, Bavaria, and Württemberg. Major parts of their states now constituted this new political territory (Fig. 2), comparable in its function to the European Community of today.

Johannes Müller was evidently an inspiring teacher with a new message: the natural order, the "system", of animal species could be discovered not by a mere description of the outer form but by the investigation of their internal organisation - and, most importantly, of their development. A prime example of his approach is his discovery of the larval development of echinoderms and some other animal forms. During his first stay on Helgoland, Müller had already pioneered the use of the microscope in the study of those small sea animals that he and his companions collected. They were helped by local fishermen, like the brothers Änkens, and, in particular, Hilmar Lührs - who later on became prominent as an advisor to many a famous zoologist. Müller made use of a net, similar to a butterfly net, except that the netting was of cloth such as that used in flour mills to sift flour. From a slow-moving boat the net was held half submerged in the water to collect those small creatures today known as plankton. After it was withdrawn, the net was turned inside out and briefly immersed in a bucket of seawater. The minute organisms held in the cloth were thus shaken loose; they settled on the bottom, and after the seawater was decanted they could be collected and transferred to microscope slides with the aid of a pipette. The type of net became known as the 'Müller Net' and is still used today in plankton fishing. Müller referred to it simply as "our small butterfly-net". 3

The term 'plankton', incidentally, was coined in 1887 by Victor Hensen (1835-1924), physiologist and marine biologist at the University of Kiel, in his report to the Royal Prussian Commission on the Scientific Investigation of the German Seas "Über die Bestimmung des Planktons oder des im Meer treibenden Materials an Pflanzen und Thieren". On the advice of the linguist Jakob Grimm, well known as a collector and editor of German fairy tales, Müller used the expression "der Auftrieb" ( $t$ h e b u oy ant, or the floating). Hensen used the Greek word 'plankton', meaning 'that which floats about' (see Porep, 1970; Gessner, 1955).

During his first stay on Helgoland, Müller discovered a strange creature (Fig. 6) which he named Pluteus paradoxus - he described it in a paper published a year later in his own journal (Müller, 1846). The taxonomic affinity of the strange creature remained a taunting mystery to be solved over the following years.

Among the students Müller had brought with him on his first trip to Helgoland were Karl David Wilhelm Busch (1826-1881), then only 19, and Robert Ferdinand Wilms (1824-1880), then 21 years old. Wilms studied the chaetognath Sagitta. Already by the following year his thesis "Observationes de Sagitta mare germanicum circa Helgoland incolente" was published in Berlin. 


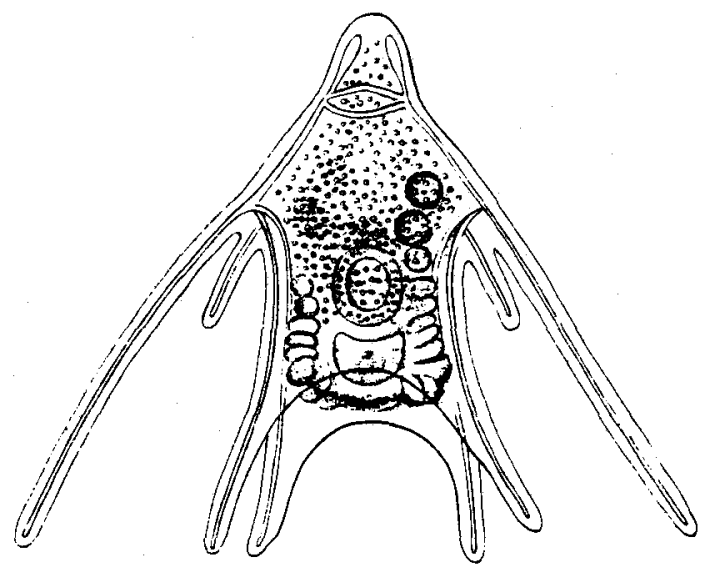

Fig. 6. The Pluteus paradoxus discovered by Johannes Müller during his first stay on Helgoland in the summer of 1845 (From Müller, 1846)

These two students were also Müller's companions on his second trip to Helgoland in 1846, on which he took along another student, Guido Richard Wagener (1822-1896) ${ }^{4}$. This sojourn on Helgoland was again most successful.

Two weeks after their arrival, Johannes Müller wrote to his son Max that they had not yet been bathing "because time is so precious". Indeed, Müller was so eager to work, that he could not sleep and was anxiously awaiting the morning sun so that he could wake his companions to start fishing. Work on the microscope started at 8 and continued until lunch - which was at half past three, and when he was finding something especially interesting, Müller did not even stop to eat but carried on into the evening - as long as there was enough daylight left for microscopy. - "Dear mother and child", he wrote on the second of September, "because of the important results it is just now impossible to quit. It is possible that my goal will be reached within eight days, but it is possible that it will take fourteen days... If I search in vain for 8 days, this will not deter me from letting each drop of water pass in review under my microscope for another 8 days with terrible patience." ${ }^{5}$ - Actually, Müller stayed until the end of September: he was able to prove that the mysterious Pluteus paradoxus was an early larval form of an ophiuroid echinoderm. Müller was now able to reconstruct the entire sequence of echinoderm development, while his students concentrated on other marine forms. No less than six publications resulted from their labours; one was published by Müller, two by Busch, three by Wagener. All appeared in 1847 in the "Archiv für Anatomie, Physiologie und wissenschaftliche Medicin" edited by Müller and generally known as "Müllers Archiv".

That same summer of 1846 two other important biologists came to the island: Heinrich Frey (1822-1890) and Rudolf Leuckart (1822-1890). We will refer to them in later sections.

Wilms later became famous as a surgeon in a Berlin clinic. Busch, after he received his medical degree, moved to Bonn, where in 1855 he too became head of a hospital department of surgery.

Once again, in 1854, Müller came to Helgoland, this time accompanied by his son 
Max Müller who in the meantime had become a medical doctor, but had a great interest in marine invertebrates. When they arrived on the island, they were met by two promising young scientists: Johannes Muller's student Adolf Freiherr von La Valette St. George (1831-1898), and former student Ernst Haeckel (who now studied under Koelliker and Virchow in Würzburg). On August 31st, Johannes Müller reports to his wife, "Very pleasant it is that we found the two young naturalists von Lavallette and Haeckel still here; they had already done rather useful work. We live in the same old apartment where we lived last time... by a stroke of luck, Lavalette already resides in the same house, and Haeckel lives nearby. Thus we make our excursion on the sea together. " ${ }^{6}$ For Haeckel, this encounter with Johannes Müller was of decisive importance and amounted to a true conversion, as we will see in a later section devoted to Haeckel.

In the letter to his wife, Johannes Müller continues: "When I encountered again my old little animals in great numbers in the sea water after the first fishing trip, I was very happy that I had decided to come here. I could not have done better, and I probably would not have been able to do better in Italy ..." and there follows a curious sentence: "With Italy it is different, there almost everything is exhausted. ${ }^{7}$ Müller did indeed fear that there he had seen and observed all there was to be seen und observed, and he was obsessed by the thought that he would soon have nothing further to discover!

That same year, 1854, the Royal Society of London bestowed upon Müller its highest honour, the Copley Medal, for his work on the development and systematics of the echinoderms.

\section{MAX SCHULTZE (1825-1874)}

We may count Max Schultze a pupil of Johannes Müller, under whom he studied for a year before returning to Greifswald for his medical doctorate in 1850. Although known mainly as a histologist (he became Professor of Anatomy at Bonn in 1859) and one of the pioneers of cell biology, he made important contributions to zoology, clearly following in the footsteps of Johannes Müller. In the August of 1851, he came to Helgoland to study Amphioxus, a favourite subject of Müller's. From the narrative of the brief paper reporting his findings, we clearly discern Müller's method: "Among numerous specimens of Noctiluca, Actinotrocha, Sagitta, Tomopteris, and small medusae I had scooped out of the sea in the midst of the most beautiful phosphorescence one night in August, I discovered, on examination next morning, two specimens of Amphioxus... These were the only ones I came across during my two weeks stay on Helgoland, and the first ones ever discovered on this island. ${ }^{8}$

\section{FRIEDRICH ANTON SCHNEIDER (1831-1890)}

Among Johannes Müller's favourite pupils was Friedrich Anton Schneider. He received his Ph.D in 1854, and in the following year he accompanied Johannes Müller on that fateful journey to Norway which ended in a catastrophe. The ship on which they returned from Bergen sank after a collision with another ship. A large number of the passengers drowned, among them Müller's assistant Schmidt. Müller and Schneider were rescued after they had drifted on the water for several hours. Müller's psyche was severely affected by the shock of this experience and this may be responsible for his early death. Schneider too needed several years to recover from the horrors of this experience. He became Kustos of the Zoologiral Museum in Berlin. Schneider was a close friend 
of the botanist Nathanael Pringsheim (1823-1894), who was later to play a major role in the founding of the Biologische Anstalt. In 1861, Schneider and Pringsheim went to Helgoland, Schneider to study the metamorphosis of Actinotrocha branchiata (a Phoronid), Pringsheim to study the reproduction of algae. After Schneider's death, Pringsheim wrote in a letter of condolence to Frau Schneider: ". . I first met him [Schneider] after his disastrous journey with Johannes Müller, during which, on their return from Norway, they were shipwrecked and by lucky chance he was rescued, together with his teacher Müller. The shocking impressions of this journey had a lasting effect also on Schneider. Through Schaum and Lieberkühn, his old friends, we became closer. This may have been in the year 1857 or 1858. From then on until 1864 when I went to Jena, we had without interruption been on intimate terms, and during this time hardly a week passed when he was not a guest in my house... From this time of our life together, I most vividly remember our joint scientific sojourn on Helgoland. There we lived under the same roof for several months, in continuous scientific and intellectual interaction, he occupied with his zoological, I with my botanical investigation of the marine organisms of the North Sea. From these most fruitful labours during August and September 1861 emerged one of the most beautiful discoveries of Schneider, that of the metamorphosis of the Actinotrocha branchiata which he published in that same year in the Monthly Report of the Berlin Academy. During those - for Schneider's work - so successful days on Helgoland, our friendship also grew firmer and remained thus until his untimely death. ..." ${ }^{9}$

It appears that Schneider was on Helgoland again in the summer of 1865: in the biography of Ferdinand Cohn (published by Pauline Cohn, 1901), F. Rosen states that, during a stay on Helgoland in 1865, Cohn was in the company of Pringsheim and that there he got acquainted with the zoologists Haeckel, Schneider, and Dohrn. Schneider's name, however, is not mentioned in any of the biographies of Haeckel, nor does Ankel, in his biographies of Schneider $(1958,1963)$, mention a second visit to Helgoland.

In 1869, Anton Schneider became Professor of Zoology in Giessen, as successor of Rudolf Leuckart. Four years later, he made a discovery of momentous importance: with the aid of a new staining method, he saw for the first time the phenomenon of mitosis: he described the aequatorial plate, and the early and the late anaphase of the chromosomes during the first cell division of summer-eggs of a platyhelminth, Mesostomum ehrenbergi. The publication (Schneider, 1873), in the journal of a local society, did not receive the attention it deserved. Indeed, the most influential anatomists and zoologists of his time did not take Schneider very seriously; Rudolf Leuckart had called him a muddlehead ("Wirrkopf"). It was one of his later successors, Wulf Emmo Ankel (1911-1984), who rehabilitated Anton Schneider, rescued his discovery from its obscurity and reclaimed Schneider's priority (Ankel, 1958, 1963).

\section{CHRISTIAN GOTTFRIED EHRENBERG (1795-1876)}

When Johannes Müller was appointed to the Chair of Physiology and Comparative Anatomy at the University of Berlin in 1833, he was also made head of the Anatomical Museum - much to the chagrin of Christian Gottfried Ehrenberg, who had contributed most of the collection housed there. Ehrenberg, already a well-known microscopist, and famous for his travels to far regions of the world, was given a couple of rooms in the 
museum and, a year after Müller's appointment, became Professor of the theory, methodology and history of medicine.

In 1835, Ehrenberg travelled to the island of Helgoland to investigate the phosphorescence of the sea, a favourite subject of his. He had discovered that the luminescence was due to several organisms which produced flashes of light when mechanically or chemically stimulated. He wrote an extensive account of this (Ehrenberg, 1836), and ascribed the spectacular phosphorescence of the sea - seen at night when boats and their oars moved through the water - to small organisms, especially a microscopic creature known as Noctiluca scintillans. It should be noted, however, that Noctiluca had long before been recognised as a source of the nocturnal luminescence: the first report was that of Henry Baker (1698-1749) in his once famous book "Employment for the Microscope" published in 1753. A travel guide book "Von Hamburg nach Helgoland" by Karl Reinhardt, published in 1856, gives a detailed description of Noctiluca (Fig. 7) and explains that the light is emitted from numerous luminous dots within the translucent body of this "little animal".

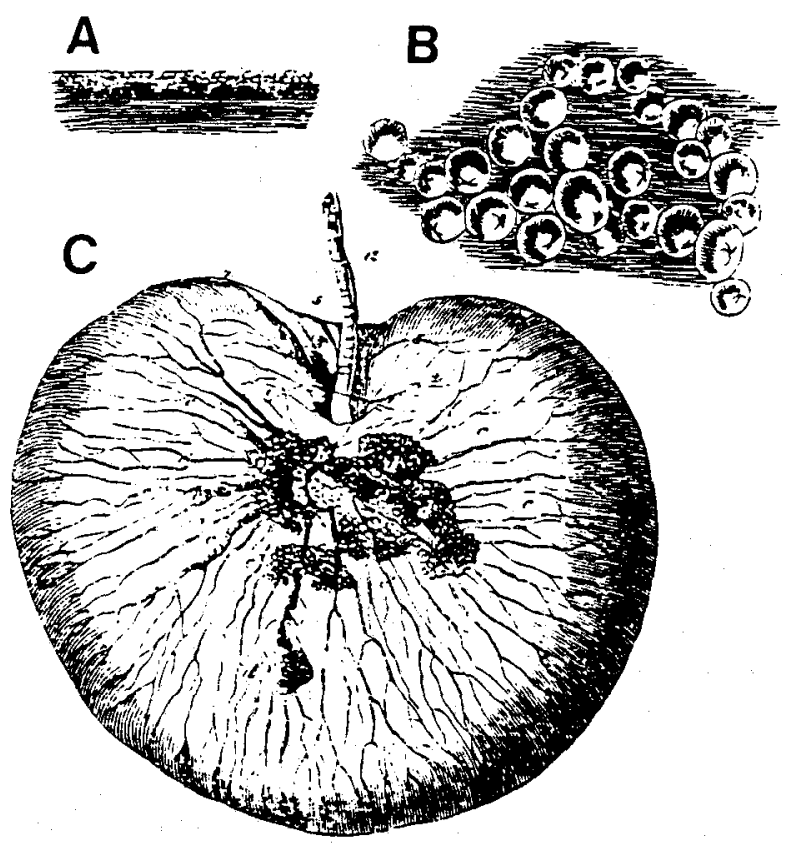

Fig. 7. Noctiluca miliaris as pictured by Reinhardt in 1856. A: Natural size; B: As seen with the aid of a magnifying glass; $\mathrm{C}$ : As seen through a microscope at still higher magnification

Ehrenberg was accompanied by a famous colleague, Rudolph Wagner (1805-1864), physiologist and comparative anatomist at Göttingen. Wagner, who had only been acquainted with terrestrial organisms before, found this experience so inspiring that he later (in 1846) sent two of his most talented students and young assistants, Heinrich Frey (1822-1890) and Rudolf Leuckart (1822-1898) to Helgoland to further explore the marine invertebrate fauna. We will return to them in the section on Leuckart. 


\section{ALBERT KOELLIKER (1817-1905)}

Müller's tales of his experiences and findings at the sea coasts excited the curiosity of his students. In 1840, two of them, Carl Nägeli (1817-1891) who was later to become a famous botanist, and his friend Albert Koelliker (both from Zürich), decided to see for themselves what sea life was like. In the late summer of 1840, they undertook a journey to the sea coast, in the company of two other Swiss students of the University of Berlin, J. Aeppli, a student of theology, and $\mathrm{H}$. Curchod, a student of medicine. They travelled by mail coach first to Lübeck, and then by Extrapost through Holstein (which at that time was still under Danish administration) to Kiel. Here they saw, for the first time, the ocean. "Kiel", wrote Koelliker to his mother, "lies rather pleasantly on an ocean bay, but this is just about the only thing that makes this town attractive." 10

Extrapost meant a little horse-drawn open wagon, with three or four benches across, from which the students enjoyed the pretty landscape, laughing and singing. Altogether it took six days to travel from Berlin to Dagebüll, a small town on the west coast of Holstein, just across from the island of Föhr. A ferry boat took them to the island where they stayed for seven weeks. Koelliker and Nägeli collected animals and plants on the sea-shore, and took great pleasure shooting sea birds, which they brought home to have cooked by the landlady. They enjoyed bathing. The students were invited by the "notables" of the island, the L a n d vog t and the local doctor, to celebrate the birthday of the King of Denmark. The students entertained their hosts with Swiss songs, and Albert Koelliker treated them to Swiss yodelling - he was a master yodeller who, throughout his life, attended the annual Swiss yodelling contest.

On October 10th, at 3 in the morning, they embarked on a two-masted sailing boat which took them over a heavy sea to the island of Helgoland where they arrived in the afternoon. Koelliker found the island breathtaking. Nägeli and Koelliker rented the upper floor of a cottage, five rooms in all, for 15 Marks a week. They got up at six in the morning and immediately went to the seashore to collect what the tide had brought in. As the tide rose, they bathed, then went home for breakfast. Afterwards they worked, using the microscope they had brought along. Koelliker worked on his thesis which he hoped he would have finished within half a year. Lunch was at three in the afternoon. The rest of the day they spent walking, collecting, bathing on the "sand dune" or joyriding in a rowing-boat. After a small meal between 7 and 8 they wrote, read or talked. This is how Koelliker described their activity in a letter to his mother. He explained that Helgoland was now the best bathing resort in Germany, with 2000 to 2500 guests each year during the bathing season - and 2400 native inhabitants. "The men are mostly fishermen and pilots (German: Lotsen). Very few foreigners live here permanently: the doctors, the English Governor, Esq. Hindmarsh, the pharmacist, the minister, and a few English families. The fishermen are rather poor ... . also the lobsters, formerly so common, are hardly worth the effort", Koelliker reports ${ }^{11}$. On October 29 th, he went by mail boat to Hamburg, while Nägeli remained on the island - with Koelliker's microscope. The small sailing boat - its total length was 25 feet - left at half-past-six in the morning; it arrived in Cuxhaven 20 hours later. The next morning "a splendid English steamer" took him to Hamburg where he arrived in the evening to continue on next day to Berlin.

The result of Koelliker's work on the island was a thesis which was completed the following spring. The topic was the "sexuality of invertebrate animals and the signifi- 
cance of the sperm-threads". The paper was printed in Berlin, and in the summer of 1841 Koelliker took it to Zürich to obtain his Ph. D. During those few days he made observations on the animal and plant life of the shores of the Limmat, the river that flows through Zürich - and under a bridge discovered eggs of two species of dipterans. He took them home and observed their development. This resulted in a new thesis - written in Latin entitled "Observationes de prima insectorum genesi, adjecta articulatorum evolutionis cum vertebratorum comparatione", which enabled Koelliker to receive an M.D. degree from Heidelberg University in 1842. Five years later, he was appointed Professor of Physiology and Comparative Anatomy at Würzburg. He remained active into the 20th century: when he reached the age of eighty, he resigned as professor of anatomy but retained his professorship of comparative anatomy, microscopy and developmental biology! Throughout his scientific life, Koelliker spent a lot of time near the sea - but he preferred the mediterranean coast. Numerous publications of the greatest importance for the new science of Zoology were the result.

\section{RUDOLF LEUCKART (1822-1898)}

Rudolph Wagner in Göttingen has already been mentioned as a companion of Ehrenberg during the sojourn on Helgoland in 1835. Wagner had two favourite students, Rudolf Leuckart und Heinrich Frey (both born in 1822). Leuckart entered the university when he was twenty, Frey when he was sixteen! Frey had studied in Bonn and Berlin before he came to Göttingen where Leuckart had already been since 1842 . They both received their doctorates in Göttingen. Wagner sent both men to Helgoland to collect and study invertebrate animals. The result was the second volume of Wagner's "Lehrbuch der vergleichenden Anatomie" (Textbook of Comparative Anatomy). It was entitled "Beiträge zur Kenntnis Wirbelloser Thiere mit besonderer Berücksichtigung der Fauna des norddeutschen Meeres", and was published in 1847. The work contained a series of monographs by the two young authors. One of them, written by Leuckart, is a land-mark in the history of Zoology, as it established the Coelenterata as a separate, new class. The book also contains a list of the invertebrate sea animals of the fauna of Helgoland. Three years later, in 1850, Leuckart was appointed to the newly created Chair of Zoology at the University of Giessen. He became one of the leading zoologists. Frey became professor in the Faculty of Medicine of the University of Zurüch, but maintained an active interest in zoology. Perhaps the most important pupil of Leuckart was August Weismann (1834-1914), later Professor of Zoology at Freiburg where he became a leading figure in the field of evolutionary biology.

Once again, in 1858, during the months of August and September, Rudolf Leuckart came to Helgoland, this time in the company of Heinrich Alexander Pagenstecher (1825-1889), Professor of Zoology at the University of Heidelberg. Their investigation was concerned with the developmental stages of certain nemerteans (Pilidium), of the chaetognath Sagitta, and of a number of Helminthes. They published their discoveries in an extensive paper in Müller's Archiv in 1858. It is interesting to read their account of their experiences: "The island of Helgoland may be described as a place particularly well-suited for helminthologists. Numerous hunters from among the islanders and visitors pursue with lead and powder those feathered guests which, at the end of summer when they are seeking the southern regions, arrive daily in ever renewed flocks for a 
short rest on the Dune and the Rock. In addition, the entire island is covered with poles to which at certain times large nets are affixed. Among the number of birds thus caught (the number of species now exceeds 320), the wading and swimming birds represent the major part. On dissecting the prey, one can be sure to encounter a large number of helminths." ${ }^{12}$

Leuckart and Pagenstecher, many years later, were among the initiators of the Biologische Anstalt Helgoland, as will be described later in the section on Anton Dohm.

\section{ERNST HAECKEL (1834-1919)}

Like Albert Koelliker in 1840, Ernst Haeckel also went to Helgoland when he was a student. But that was 14 years later, in 1854. Haeckel studied Medicine at the University of Würzburg, where Rudolf Virchow and Albert Koelliker were his teachers. In the autumn of 1853 he had gone for a year to Berlin where he avidly followed the lectures of Johannes Müller, whom he worshipped. Müller had told him of the joys of what he called "pelagic fishing". "Once you have tried it", he said, "you remain in its thrall." Haeckel, then just twenty, went together with his friend Adolf Freiherr von La Valette St. George, aged 23 - also a student and admirer of Johannes Müller. Haeckel was a good and faithful writer of letters. So we have his first-hand account of Helgoland as it was in 1854 . A three-masted steamer (see Fig. 8) had taken the friends to the island. It was a stormy crossing and Haeckel was in absolute bliss when the boat plunged headlong into the "flood-valleys" and when "the waves clashed high above our heads. ... And what joy each time when we became totally soaked". Apparently, Haeckel did not get seasick: "I consider this first sea journey ... certainly as one of the most beautiful and pleasurable experiences of my entire life" he reported to his parents. ${ }^{13}$

The letter continues: "At 4 in the afternoon, the beautiful three-masted steamer anchored between Helgoland and the Dune (or sand-island). Soon several boats

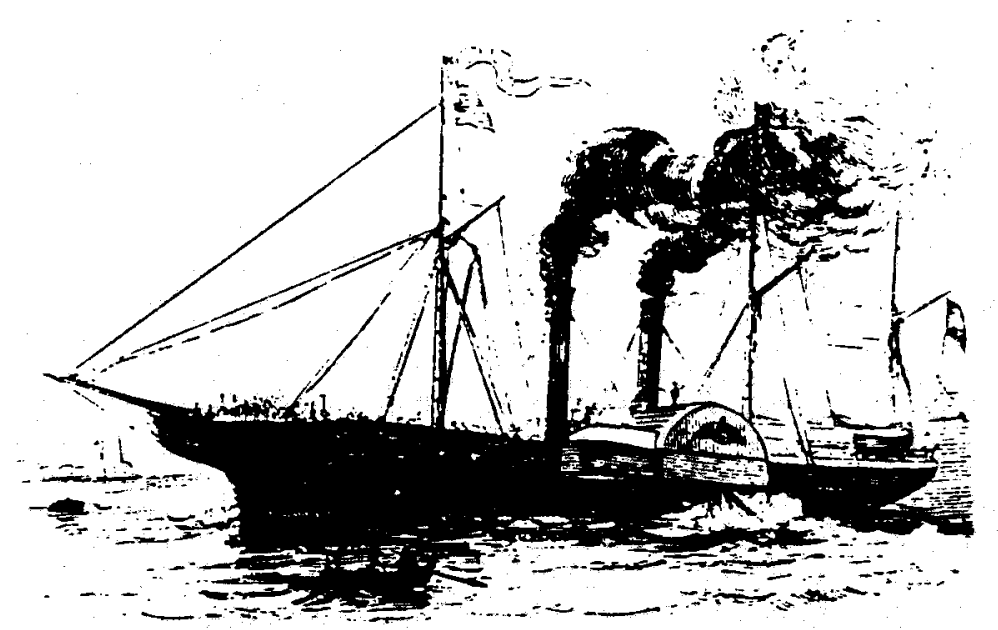

Fig. 8. A three-masted steamer that plied between Hamburg and Helgoland (From Reinhardt, 1856) 
appeared, manned by Helgolanders, to carry the poor passengers who already suffered from seasickness, to the longed-for island. Here, however, there was another hardship to be overcome: from the beach up to the houses (about 80 paces), with each arrival of the ship, a barrier is put up on either side of the three-foot-wide path along which the passengers must pass. Here - as soon as the three gunshots signal the arrival of the vessel - the entire crowd of natives and guests of Helgoland now assembles, and they loudly count the newcomers and, in the rudest and most unconcerned manner, make critical and other remarks about them. If you are not prepared for this horrid welcome, you hardly know how to escape as fast as possible from this veritable running of the gauntlet." 14

This odd custom of forming a "slander alley" to greet newcomers apparently persisted for several years (it is illustrated in Figure 9, taken from a travel-guide published in 1856). Haeckel and La Valette found comfortable quarters, however, and immersed themselves in exploring, collecting and studying the new world of marine organisms.

Everything changed when Johannes Müller arrived on Helgoland, together with his son Max Müller. Excitedly, Haeckel reports to his parents: "On Tuesday, as we inspected - as part of "slander alley" - the new incoming passengers that had just arrived on the steamer, we noticed to our joy and surprise Johannes Müller, our greatest and most exalted authority, whose arrival we had so fervently hoped for, but no longer expected. He arrived with his son, Max Müller, who is Dr. med., to study the larvae and developmental stages of starfish, sea urchins, etc. The discovery of the developmental history of these animals has to no small degree established Müller's fame... As we greeted them, they welcomed us very cordially and we decided to jointly go out collecting. Through this our entire occupation and time-schedule has all of a sudden now taken a new direction. We have given up our own collecting, drying of algae, preserving animals and dissecting. Instead we go out daily with the Müllers for 1 to 2 hours onto the open sea where - with the aid of dip nets - in a short time we catch thousands of the most lovely creatures,

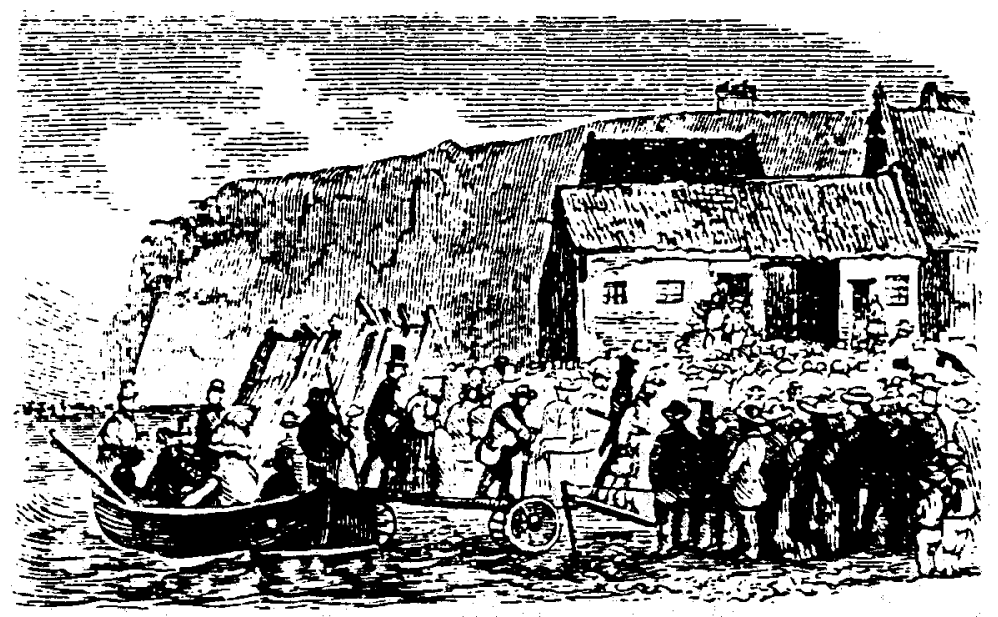

Fig. 9. "Slander alley" as depicted in a contemporary travel guide (Reinhardt, 1856) 
mostly developmental stages of invertebrate animals, Radiata, worms, and crustaceans. The rest of the day is then occupied with observing the animals with the microscope." 15

The results of the research efforts on Helgoland were published the following year (1855) in the "Archiv für Anatomie, Physiologie und wissenschaftliche Medicin" (in short: "Müller's Archiv") of which Johannes Müller was the editor. Haeckel's paper "Ueber die Eier der Scomberesoces" treated of the eggs of a group of bony fishes ${ }^{16}$; Max Müller had two papers ("Ueber die weitere Entwickelung von Mesotrocha sexoculata"; "Ueber Sacconereis Helgolandica"), and Johannes Müller one: "Fortsetzung der Beobachtungen über die Metamorphose der Echinodermen".

For Haeckel, this first experience of marine zoology had a profound effect. He decided then and there to become a marine zoologist. He had dreams of exploring the sea coast of the tropics. On the day the Müllers arrived on the island, Haeckel wrote to his parents: ". . my decision now stands firm to henceforth investigate tropical sea coasts as a naturalist, namely zoologist." ${ }^{17}$ In 1855, Haeckel transferred to Würzburg where he became Assiste $\mathrm{nt}$ to Rudolf Virchow. In the autumn of that year, he accompanied Albert Koelliker to Nizza where they studied marine animals. Afterwards Haeckel again returned to Berlin where, in 1858, he obtained his medical doctorate. Three years later he moved to Jena where, in 1862, he became Professor Extraordinarius of Zoology in the Department of Anatomy of the medical school. Two years later, the Faculty of Philosophy bestowed upon him the degree of Doctor of Philosophy and appointed him to its new Chair of Zoology. The year before, it had already appointed Nathanael Pringsheim to the new Chair of Botany.

La Valette St. George moved to Bonn where he became Dozent in 1858, Pros e k tor in 1859, Professor Extraordinarius in 1862 and Professor of Anatomy in 1875.

When Haeckel returned to Helgoland again (on August 17th of 1865) he had just been appointed Professor of Zoology. He was accompanied by his assistant, Nikolai Nikolajevic Miklucho-Maclay (1846-1888), who later became famous as a founder of evolutionist paleontology. Also in their company were Anton Dohrn (see below) and two other zoologists (see the article by Zissler, this issue). By then the political landscape had undergone considerable change. Austria and Prussia had made war against Denmark, and a few months later, in October of 1864 (Treaty of Vienna), they became occupying powers of the province of Schleswig (now under Prussian rule) and that of Holstein (now administered by Austria). The German Confederation (Deutscher Bund) had become replaced by the North German Confederation (Norddeutscher Bund, see Fig. 10). Helgoland, however, remained British.

\section{FERDINAND COHN (1828-1898)}

When the zoologists Ernst Haeckel, Anton Dohrn, and - possibly - Anton Schneider (see the letter of Pringsheim, quoted in the section on Schneider) were on the island in 1865. Helgoland was also the domicile of the botanists Nathanael Pringsheim and Ferdinand Cohn. Pringsheim was then Professor of Botany and had been (since 1864) in Jena. He was interested in algae, especially their sexual reproduction (for details, see Jahn, 1990).

Pringsheim worked on the island many times (see Heincke, 1899), and was later to become the prime mover in establishing the Biologische Anstalt Helgoland. His story is 


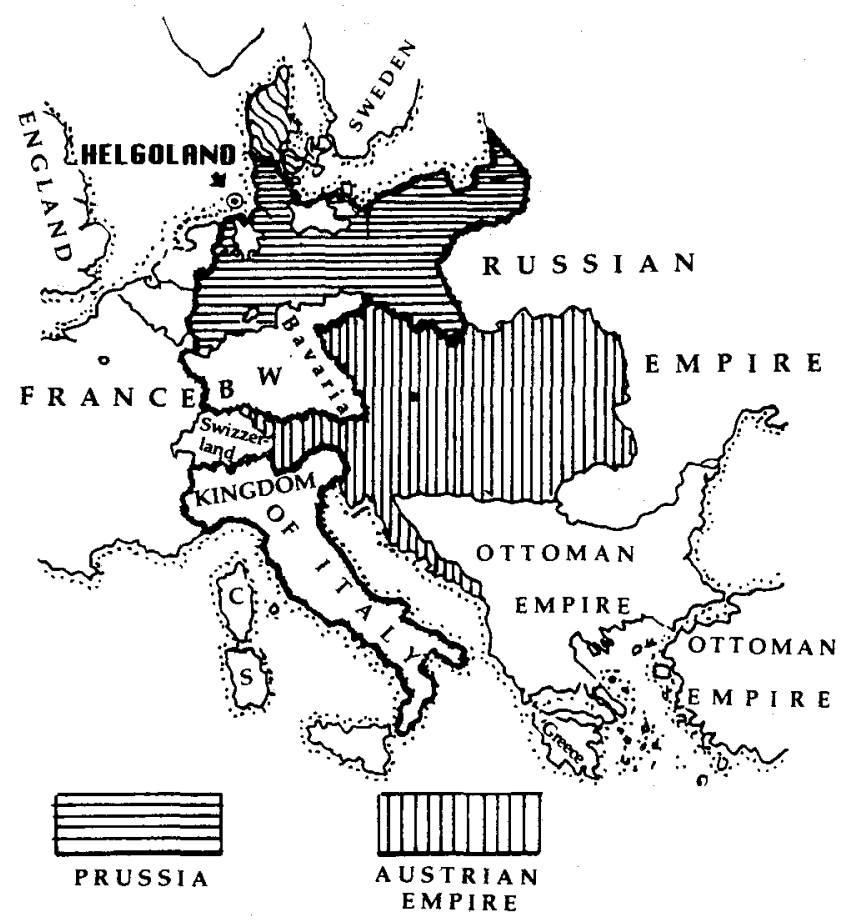

Fig. 10. Sketch of the political map of central Europe in 1871. The Second German Reich and the Kingdom of Italy are indicated by heavy lines. The southern border of Prussia marks the southern boundary of the former North German Confederation. B = Baden, $W=$ Württemberg; $C=$ Corsica, $\mathrm{S}=$ Sardinia. Schleswig and Holstein were now part of Germany. Helgoland still remained British

the subject of a separate article by Mollenhauer in this issue (see also Mollenhauer \& Lüning, 1988). Ferdinand Cohn, a pupil of Chr. G. Ehrenberg in Berlin, had been appointed Professor Extraordinarius at the University of Breslau in 1861. He founded the Institute of Plant Physiology there, and the first research institute of Bacteriology and Microbiology. His most famous co-worker was Robert Koch (1843-1910).

In a letter, written in the September of 1865 , Cohn says: “The days of my sojourn are gradually coming to a close, and the time appears to be as short as if it were but one day. The weather here has been very favourable, and to this day it is indescribably mild and balmy. This time I did not have much social entertainment; however, I got all the more pleasure out of my scientific fishing hauls, and examining them afterwards - which brought new discoveries every day. When the weather is good, it is wonderful to go out in a little boat and to pull up from the bottom the creatures of the deep, or to step out onto a cliff, exposed at low tide, to collect animals and the plants that grow there. When one gets home, one finds that one has, without realizing it, collected the best. I must have worked each day until late at night with my microscope, and today I did not even find the time to go bathing. After lunch (that is, after five), however, I laze about. I have so much opportunity here to see and to learn, that I find it most difficult to decide to leave. "18 
When he came to Helgoland a second time, in 1865, Haeckel was accompanied by his former student Anton Dohrn who, a few months earlier in Berlin, had failed his doctoral exam. For Dohrn this had been a most unsettling experience and he needed the strong hand of his friend and former teacher Ernst Haeckel, to be put on the right track. Haeckel himself was in need of company. Only the year before, he had lost his beloved wife and had consequently suffered a deep depression. When Haeckel made his four companions pose for the historic photograph (see the article by Zissler, this volume), Dohrn's mind was evidently elsewhere. He looks aloof - if not a bit hostile. It appears that his Helgoland experience was not a happy one. After their return to Jena, Haeckel and Dohrn became estranged. Haeckel did not think Dohrn had it in him to become a zoologist. How mistaken he was! Five years later, in 1870, Anton Dohrn founded the world-famous Zoological Station (now Stazione Zoologica "Anton Dohrn") at Naples, the mecca of zoologists for the next hundred years, and a model for the biological station (Biologische Anstalt) to be founded on this island of Helgoland twenty seven years after Dohrn had been here.

Anton Dohrn had a vision of a new kind of zoology, the experimental approach to evolutionary theory. A year before he had accompanied Haeckel to Helgoland, Dohrn had already published a paper with the programmatic title. "The theory of Darwin and the experiment". Dohrn was very impressed by Johannes Müller - who had inspired many of his pupils (von Helmholtz, Du Bois-Reymond, Ernst Brücke) to become experimental biologists - and he regarded him as the founder of marine biology. Dohrn later named the first research ship of his Zoological Station "Johannes Müller". When he was on the island of Helgoland, however, Dohrn must have felt frustrated by the kind of oldfashioned descriptive zoology - and by the lack of proper research facilities. Could this frustration have been the seed of the new concept of a marine-research facility?

While on Helgoland, Dohrn was not idle. He immersed himself in the study of crustaceans and, as a result of his researches, published a paper on the natural history of Caprella (Dohrn, 1866). In fact, after his return to Jena (and after he succeeded in obtaining his doctoral degree in Breslau), Dohrn expanded his interest in crustaceans and turned to philosophy. His vision of a "new zoology" never left him, however. He travelled to Messina in the footsteps of Carl Vogt (1817-1895), who had already tried to establish a marine laboratory there. There in Messina, he joined Haeckel's assistant MikluchoMaclay, who was one of the members of Haeckel's party on Helgoland (see Zissler, this volume). Dohrn returned to Jena the following year, when he noted that Haeckel's kind of zoology had declined in popularity and the number of zoology students had declined from a former three hundred to not more then thirty.

In early January of 1870 , Dohrn decided on a plan to establish a "zoological station" - not in Messina but in Naples. The story of how this came about need not be repeated here; it has already been told elsewhere in detail (Heuss, 1940, 1962; Kühn, 1950; Florey; 1985). For a time, politics intervened. The North German Confederation, joined by a customs treaty with southern Germany, headed for a confrontation with France, and in 1870, France declared war on the Confederation. Anton Dohrn was drafted into the army. When the Emperor of France, Napoleon III, was captured and brought to Kassel, Anton Dohrn was among the soldiers guarding the train. The military victory over France in 
1871 created a new political landscape and saw the foundation of the Second Reich under the leadership of Prussia, and the creation of the kingdom of Italy (see Fig. 10). With Naples now aligned with the new Italian government, and Prussia much in favour with the Italians, the road was clear for the realisation of Dohrn's great dream, the foundation of a zoological research institute on the mediterranean coast. Although he used his private funds, the new Zoological Station depended on (German) public funds. For Anton Dohrn the establishment of the new German Reich meant a double chance of obtaining financial support for the enterprise he planned for Naples since now the government of Prussia (with whom he had negotiated), and the new Federal Government, were both supporting science. Dohrn's Zoological Station opened its doors only two years after its inception. Under his leadership it became the most important, and the most successful, zoological institution in the world.

Anton Dohrn's project stimulated much discussion among German biologists, and an effort was made to establish a marine research laboratory nearer to home. In 1876, the Gesellschaft Deutscher Naturforscher und Ärzte held their annual meeting in Hamburg and passed a resolution recommending the establishment of a zoologico-botanical station on the island of Helgoland. It was signed, among others, by Alexander Pagenstecher, the zoologists Ernst Haeckel (Professor of Zoology at Jena since 1865) and Rudolf Leuckart (Professor of Zoology at Leipzig since 1869), and the botanists Julius Sachs (1832-1897; the founder of plant physiology) and Nathanael Pringsheim, whose private laboratory in Berlin pioneered experimental botany and who was a powerful member of the Berlin Academy of Science.

Schleswig and Holstein had become part of the new Germany, and Helgoland was considered by many to be a German island (see Mollenhauer, this issue). British presence on the island was only nominal. The British journal "Nature" immediately reported on the new plan for a biological laboratory on Helgoland. The report ${ }^{19}$ ends with the words "It is not necessary to say one word in commendation of this admirable scheme; we cannot doubt that it will be successfully carried out." A rather neutral statement. Dohrn feared that government funds otherwise available for Naples might now be siphoned off. To his friend Charles Grant (1841-1889) he wrote "that gang tries to blow me up . . but the entire mob shall feel that I have enough strength to parry their attack. ${ }^{20}$ He went to Berlin to prevent the scheme. His friend Francis Maitland Balfour (1851-1882) who liked to work at the Naples Zoological Station, published a worried note in the next issue of "Nature", ${ }^{21}$ stating that "It is indeed surprising to see a body of German naturalists refusing their support to an institution like that at Naples, which has already rendered such signal services to biology ... and which is, moreover, founded almost on the site of the classical investigations of Koelliker, Gegenbaur, and Haeckel.".

A year later, Dohrn felt sufficiently assured of financial support for the Naples laboratory, that he published a third note in "Nature"22, in which he said that Mr. Balfour had mistaken the intentions of the German biologists and that he [Dohrn] had been assured of undiminished funding. After all, Dohrn himself had earlier publicly recommended his Zoological Station as a model for other stations to be founded all over the world. He felt that the creation of a marine laboratory on Helgoland would confirm that his beliefs were well-founded. Indeed, several marine stations had meanwhile been established in Normandy, Trieste, Sebastopol and elsewhere. "It may be", Dohrn wrote, "that too little circumspection has been used in founding or planning several of these 
institutions; nevertheless their great number and rapid augmentation justify me in giving to my establishment such dimensions and so distinct an international character as to carry it as far beyond competition as possible." 23 Dohrn was not to be dwarfed!

\section{HANS DRIESCH (1867-1941)}

In the summer of 1888, Hans Driesch, a pupil of August Weismann and of Ernst Haeckel, came to Helgoland to collect and study hydroids for his planned thesis. He spent four weeks there. In his autobiography, he reports that "a not-too-seaworthy steamer" carried passengers to the island twice a week (Driesch, 1951). It was hardly noticeable, he says, that Helgoland was still under British rule "except for the heads of Queen Victoria on the postage stamps. There was no customs formality. Only five Englishmen lived on the island, the old Governor .... and 4 'coast guards' who had to operate the three little guns, the only armament of the island, for the purpose of saluting when, once a year, the British warship arrived in order to convince itself that the island was still there. "24 Driesch was still able to find one of the old fishermen who had served Johannes Müller and Haeckel. Hilmar Lührs was his name. Driesch lived in Lührs' house and was helped by him in the collecting by boat or on the cliffs.

During his seventh semester at Jena, Driesch was already showing his teacher Ernst Haeckel the draft of his paper that resulted from his Helgoland work. Haeckel told him that there was no need to rewrite or copy the paper and that it would be acceptable as a thesis. In the summer of 1889, Driesch passed his Ph.D exams summa cum laude. Almost immediately afterwards he went to England to work at the Marine Laboratory at Plymouth that had just opened its doors. A journey to India followed, and in 1890 Driesch was once again on the island of Helgoland. He came earlier in the year when the tourists had not yet arrived. In the quiet of the island, he pondered the problems of embryology, and it was here that he conceived the notion of a causal analysis of the processes involved in morphogenesis during development, stimulated by the new ideas of Wilhelm Roux's "Entwicklungsmechanik". Driesch later went to Trieste in pursuit of this new research programme, and in 1891 went to the Zoological Station in Naples to carry out the famous experiments on sea-urchin embryos, in which he analyzed the development from fertilised egg to the Pluteus-stage.

Through painstaking observations, Johannes Müller had laid the groundwork. On the island of Helgoland he had discovered that strange creature he named Pluteus paradoxus. And, on Helgoland, he had recognised its nature as a larval form of an echinoderm. More than forty years later, the time was ripe for Driesch to carry out the experimental analysis of this metamorphosis - conceived on Helgoland and carried out from 1891 onwards at Naples.

\section{CONCLUSION}

A year after Hans Driesch left Helgoland, England ceded the island of Helgoland to the German Reich in exchange for Witu and Zanzibar. Emperor Wilhelm II came to Helgoland to take over the island. Two years later, the German government agreed to the founding of a marine laboratory on Helgoland. In 1892 the Biologische Anstalt Helgoland opened its doors - and we are here today to celebrate its one-hundredth anniversary! 
Acknowledgements. This study has been supported by grants from the University of Konstanz (3/73) and the Deutsche Forschungsgemeinschaft (Fl 8/9-1). I am grateful to Dr. Christiane Groeben, curator of the Dohrn Archives at the Stazione Zoologica "Anton Dohrn" in Naples for making available the materials of the Archives and for various kinds of help and advice. I thank Dr. Ilse Jahn (Berlin) for important comments and information concerning Christian Gottfried Ehrenberg. Her wonderful book "Gründzüge der Biologiegeschichte" (Jena, 1990) has been an inspiration. Inka Renckhoff, Librarian of the Biologische Anstalt Helgoland, was most helpful whenever I needed material from the Library. I am indebted to Dr. Dieter Mollenhauer (Forschungsinstitut Senckenberg, Lochmühle), to Dr. Dieter Zissler (Institut für Biologie I, Universität Freiburg), to Professor Christian Hünemörder (Institut für Geschichte der Naturwissenschaften, Mathematik und Technik, Universität Hamburg), and to an unknown referee for valuable advice and for critically reading the manuscript. Dr. Zissler referred me to the work of K. W. v. Dalla Torre, "Die Fauna von Helgoland", published in 1889, which contains important details of zoological research on Helgoland and an extensive list of references. I regret that this publication was unknown to me when I wrote this account of early Biology on Helgoland and I urge the interested reader to consult it! I owe special thanks to the copy editor on the "Helgoländer Meeresuntersuchungen", Andy Godfrey, for painstaking attention to detail and for putting a final polish to my manuscript.

\section{NOTES}

1 "Die Helgoländer sind ein ziemlich müßiges Volk . . . Die Helgoländer sind schon deshalb vom größeren Fischfang ausgeschlossen, weil sie keinen Hafen besitzen, die Schiffe im Winter zu bergen... Ihre Fahrzeuge taugen zu nichts als nach der Düne zu fahren... Der Menschenschlag ist hübsch; man spricht deutsch, ißt deutsch. Alles drängt sich Nachmittags am Conversationshause hier unten zusammen; man ist sehr ungeniert..." (Letter of August 19th, 1845, Haberling, 1924, p. 281 ff.)

2 "Jedes wird zum Ereignis, die Ankunft eines Dampfschiffs, wie eines fernen Segelschiffs, und den ganzen Tag über ist der Strand voll von Menschen, die zum Baden überfahren, die Lustfahrten machen, die an der Brandung Kaffee trinken." (Haberling, 1924, p. 283)

3 The net can be seen prominently displayed in the photographs described by Zissler (this volume)

4 In the biographies of Johannes Müller by Haberling (1924), and Koller (1958), the name is erroneously given as Karl Ernst Albrecht Wagner, 1827-1871.

5 “Es ist mir gerade in den wichtigsten Ergebnissen nicht möglich abzubrechen. Es ist möglich, daß ich in 8 Tagen zum Ziel käme, es ist möglich, daß es noch vierzehn Tage währt. . . Wenn ich noch 8 ganze Tage vergeblich suche, so wird mich das nicht abhalten, mit entsetzlicher Geduld noch 8 Tage jeden Tropfen Wasser die Revue unter dem Mikroskop passieren zu lassen." (Haberling, 1924, p. 293 ff.)

6 "Sehr angenehm ist, daß wir die beiden jungen Naturforscher von Lavalette und Haeckel noch fanden, die sich schon recht nützlich beschäftigt haben. Wir wohnen in der alten Wohnung, wo wir das letzte Mal wohnten. ... Ein glücklicher Zufall wollte es, daß von Lavalette schon in demselben Hause wohnte, Haeckel ist nahebei. Daher wir die Excursionen auf dem Meer gemeinschaftlich machen.". (Letter of August 31st, 1854, quoted by Haberling, 1924, p. 408)

7 "Als ich meine alten Thierchen in dem Meerwasser nach der ersten Fischerei äußerst reichlich wiederfand, war ich sehr glücklich, daß ich diesen Weg eingeschlagen. Ich hätte nichts besseres thun können, und ich hätte vielleicht in Italien nicht so viel weiter arbeiten können, . . . Mit Italien ist es anders, da ist fast alles erschöpft." (Ibid).

8 "Unter vielen Ophiuren-, Anneliden- und Ascidienlarven, zahlreichen Exemplaren von Noctiluca, Actinotrocha, Sagitta, Tomopteris und kleinen Medusen, welche ich bei Helgoland während des schönsten Meeresleuchtens in einer Augustnacht schöpfte, fand ich bei der Untersuchung zum anderen Morgen zwei Exemplare von Amphioxus von 11/4-11/2 Linien Länge. Es sind dies die einzigen, welche mir während eines vierzehntägigen Aufenthalts auf Helgoland vorgekommen, und die ersten, welche auf dieser Insel überhaupt gefunden sind." (Schulze, 1851, p. 416)

9 "Ich lernte ihn erst nach seiner verhängnisvollen Reise mit Johannes Müller kennen, auf welcher er beim Rückwege von Norwegen Srhiffhrurh litt und durrh einen glücklichen 7ıfall mit seinem 
Lehrer Müller gerettet wurde. Die erschütternden Eindrücke dieser Reise haben auch auf Schneider lange nachgewirkt. Durch Schaum und Lieberkühn, seine älteren Freunde, sind wir Beide uns damals näher getreten. Es mag im Jahre 1857 oder 1858 gewesen sein. Von da an bis 1864, wo ich nach Jena ging, haben wir dann ununterbrochen und intim verkehrt und es verging in dieser Zeit wohl kaum eine Woche, in der er nicht Gast in meinem Hause war. . . . Mir selber stehen aus der Zeit meines Zusammenlebens mit Schneider am lebendigsten die Tage unseres gemeinsamen wissenschaftlichen Aufenthaltes in Helgoland in Erinnerung. Wir haben dort mehrere Monate unter einem Dach nebeneinander gelebt und in stetem wissenschaftlichen Austausch unserer Arbeiten, er seinen zoologischen, ich meinen botanischen Untersuchungen der Nordsee oblegen. Jenen fruchtbaren Arbeiten im August und September 1861 in Helgoland entstammt auch eine der schönsten morphologischen Entdeckungen Schneider's, der die Metamorphose der Actinotrocha branchiata, die er noch im selben Jahre im Oktoberheft der Monatsberichte der Berliner Academie veröffentlicht hat. In jenen für Schneiders Arbeiten so erfolgreichen Helgoländer Tagen hat sich auch unser Freundschaftsbündnis fester gestaltet, welches sich ungetrübt bis zu seinem vorzeitigen Tode erhalten hat . ." (Letter of February 24th, 1890, published by Ankel, 1963)

10 "Kiel ist an einem Meerbusen recht hübsch gelegen, doch ist dies beinahe das einzige, was die Stadt anziehend macht." (Letter of August 25th, 1840, quoted by Koelliker, 1899, p. 49 ff.)

11 ". . . sind die Männer fast alle Fischer oder Lootsen. .. . Beständig hier wohnende Fremde sind sehr wenige da, die Ärzte, der Gouverneur Esqu. Hindmarsh, der Apotheker, der Geistliche und ein paar englische Familien. . . . Die Fischer sind meist arm, . . auch die Hummern, die früher häufiger waren, lohnen die Mühe kaum mehr." (Koelliker, 1899, p. 60 ff).

12 "Die Insel Helgoland dürfte als ein Ort bezeichnet werden, welcher sich ganz besonders zu helminthologischen Untersuchungen eignet. Eine Menge Jäger aus der Zahl der Insulaner und Badegäste stellen mit Pulver und Blei den gefiederten Gästen nach, welche, von Ausgang des Sommers an den Süden suchend, in täglich erneuten Schwärmen auf Düne und dem Felsen kurze Rast machen. Überdies ist die ganze Insel mit Stangen besetzt, an denen zu geeigneter Zeit große Fangnetze ausgepannt werden. Unter den auf diese Weise erlegten (bereits die Zahl von 320 Species überschreitenden) Vögeln bilden Schwimm- und Watvögel einen ganz bedeutenden Antheil, so dass man bei Zergliederung der Beute einer großen Anzahl von Helminthen zu begegnen sicher sein kann." (Leuckart \& Pagenstecher, 1858, p. 600)

13 ... [wenn das Schiff "wieder, wie ein Sturmvogel, tief kopfüber in] die Fluttäler [hinabtauchte, daß] die Wellen hoch über unseren Köpfen zusammenschlugen... Und welches Jauchzen jedesmal, wenn wir so total durchnäßt wurden" ... "Ich halte diese erste Seefahrt, lauf die ich mich so lange, lange vorher gefreut,] unbedingt für eines der schönsten und genußreichsten Ereignisse meines ganzen Lebens." (The quotations are from a letter reprinted in Haeckel, $1921 \mathrm{a}$, p. $115 \mathrm{ff}$.

14 “Um 4 Uhr nachmittags ging der schöne dreimastige Dampfer zwischen Helgoland und der Düne (oder Sandinsel) vor Anker. Alsbald erschienen mehrere mit Helgoländern bemannte Boote, welche die armen, meist von der Seekrankheit jämmerlich mitgenommenen Passagiere dem kleinen langersehnten Eiland zuführte. Hier war aber noch eine harte Probe zu bestehen. Vom Strand nämlich bis zu den ersten Häusern, ungefähr 80 Schritt; wird bei jeder Ankunft des Schiffs eine Barriere aufgestellt, auf jeder Seite des 3 FuB breiten Weges, den die Fremden passieren müssen. Hier versammelt sich nun, sobald die drei Kanonenschüsse die Ankunft des Dampfboots gemeldet haben, die ganze Bade- und Einwohnerwelt von Helgoland, zählt die Neuankommenden der Reihe nach ganz laut und macht auf die unverschämteste und ungenierteste Weise ihre kritischen und sonstigen Bemerkungen über dieselben. Wenn man nicht vorher auf diesen schauderhaften Empfang gefaßt ist, weiß man wirklich kaum, wie man möglichst rasch und unbeobachtet durch diese wahre Spießrutengasse hindurch kommen soll." (Ibid.)

15 "Als wir Dienstag nachmittag in der "Lästergasse" die mit dem Dampfboot neu angekommenen Passagiere musterten, bemerkten wir unter diesen zu unserer nicht geringen Freude und Überraschung Johannes Müller, unsere größte und erhabenste Autorität, deren Hiersein wir uns so sehr gewünscht, aber kaum noch gehofft hatten. Er kam mit seinem Sohne, Max Müller, welcher. Dr. med. ist, um hier die Larven und Entwicklungsstufen der Echinodermen, d. $h$. Seesterne, Seeigel usw., zu studieren. Die Entdeckung der Entwicklungsgeschichte dieser höchst merkwürdigen Tiere hat Müller seinen Ruhm nicht zum kleinsten Teil verschafft, ... Als 
wir sie begrüßten, bewillkommneten sie uns sehr freundlich und verabredeten sogleich mit uns, unsere Ausfahrten zum Seetierfischen usw. gemeinschaftlich zu machen. Dadurch hat nun unsere ganze Beschäftigung und Zeiteinteilung mit einem Male eine ganz andere Richtung genommen. Das Sammeln, Tangetrocknen, Ziereinlegen und Sezieren hat aufgehört, und wir fahren statt dessen täglich früh mit beiden Müllers auf das offene Meer 1 bis 2 Stunden hinaus, wo wir mit dem Schöpfnetz in kurzer Zeit Tausende der reizendsten Geschöpfe, meist Entwicklungsstufen wirbelloser Tiere, Radiaten, Würmer und Krustazeen, fangen, zu deren Mikroskopieren wir nun die ganze übrige freie Zeit verwenden ..." (Letter of August $18^{\text {th }}, 1854$, Uschmann, 1984, p. 35)

16 See the contribution of Zissler, this volume

17 "daß mein Entschluß, künftig als Naturforscher, nämlich Zoolog, tropische Seeküsten zu untersuchen, jetzt feststeht ..." (Letter of August $30^{\text {th }}, 1854$, Uschmann, op. cit., p. 33)

18 "Die Tage meines Aufenthaltes gehen nun allmählich zu Ende, und es kommt mir die Zeit so überaus kurz vor, als wäre es nur ein Tag gewesen. Das Wetter war hier recht günstig, und bis auf den heutigen Tag ist es hier unbeschreiblich mild und mollig. Viel gesellige Zerstreuung habe ich diesmal nicht gehabt, desto mehr Vergnügen machten mir die wissenschaftlichen Fischzüge und Untersuchungen, die mir täglich Neues brachten. Es ist wunderschön bei gutem Wetter im kleinen Boot herumzufahren und bald vom Meeresgrunde die Geschöpfe der Tiefe heraus zu heben, bald auf einer der von der Ebbe entblößten Klippen auszusteigen und die dort wachsenden Pflanzen und Thiere einzusammeln. Kommt man dann nach Haus, so findet man, daß man das Schönste gerade, ohne es zu ahnen, mitgebracht hat. Ich habe wohl täglich bis spät zum Nachmittag mikroskopirt und heut sogar zum Baden nicht Zeit gefunden. Nach Tisch, d. h. nach fünf, dagegen wird gebummelt. Ich habe hier soviel Gelegenheit zu sehen und zu lernen, daß ich mich nur schwer entschließe, von hier abzureisen." (Cohn, 1901, p. 140)

19 Nature 14: 535, 1876

20 "die Bande sucht mich in die Luft zu sprengen, ... nun, ... die ganze Brut soll noch fühlen, daß ich Manns genug bin, auch diesen Schlag zu parieren." (Letter of October $15^{\text {th }}, 1876$, reprinted in full in Heuss, 1962, p. $416 \mathrm{ff}$.)

21 Nature 14:570,1876

22 Nature 15: 57,1877

23 Ibid

24 "nur an den Köpfen der “Königin Viktoria auf den Briefmarken [merkte man eigentlich, daß man im Britischen Imperium war]. Zollrevisionen gab es auch nicht - . . Nur fünf Engländer waren auf der Insel: der Gouverneur, damals ein alter Herr, der Gouverneur von Kanada gewesen war ... und 4 "Coast Guards", welche drei kleine Kanönchen, die einzige "Bewaffnung" der Insel, beim Salutschießen zu bedienen hatten, wenn, einmal im Jahr, das britische Kriegsschiff kam, um sich zu überzeugen, daß die Insel noch da sei.“ (Driesch, 1951, p. 45), 1876

\section{LITERATURE}

\section{A) HELGOLAND, POLITICAL AND SOCIAL HISTORY}

Anonymous, 1876. Note on the proposal for the establishment of zoologico-botanical stations on the German coast. - Nature, Lond. 14, 535.

Balfour, F. M., 1876. The proposed zoological stations at Kiel and Heligoland. - Nature, Lond. 14, 570.

Dohrn, A., 1877. The foundation of zoological stations in Heligoland and Kiel. - Nature, Lond. 15, 57.

Gessner, F., 1955. Hydrobotanik I: Energiehaushalt. Dt. Verl. der Wissenschaften, Berlin, 517 pp.

Mohrhenn, W., 1928. Helgoland zur Zeit der Kontinentalsperre. Diss., Univ. Köln, 87 pp.

Mollenhauer, D. \& Lüning, K., 1988. Helgoland und die Erforschung der marinen Benthosalgen. Helgoländer Meresunters. 42, 385-425.

Oetker, F., 1855. Helgoland. Duncker, Berlin, 585 pp.

Packroß, J., 1952. Vom Schmugglernest zum Nordseebad. In: Helgoland ruft. Hrsg. von J. Packroß \& P. Rickmers. Schultheis, Hamburg, 71-79.

Reinhardt, K., 1856. Von Hamburg nach Helgoland. Weber, Leipzig, 142 pp. 
Spiering, W. F., (1809) 1901. Kurze Erzählung der Einnahme der Insul Helgoland, und des Betragens der Engelländer daselbst. Z. Ges. schlesw.-holst. Gesch. 31, 197-207.

Spendel, J. W. (Hrsg.), 1876. Tageblatt der 49. Versammlung Deutscher Naturforscher und Aerzte in Hamburg vom 18. bis 24. September 1876. Friedrichsen, Hamburg, 1876.

Of special interest:

p. 90 (VII. Section für Zoologie und vergleichende Anatomie): reference to a lecture by "Dr. Kossmann aus Heidelberg: Ueber die Nothwendigkeit der Errichtung einer zoologischen Station in der Nordsee", p. 115: "Mittheilung des Fischers Herrn Hilmar Lührs aus Helgoland über Zeit und Umstände des Vorkommens gewisser Seethiere in Helgoland. Von Prof. A. Pagenstecher;" and pp. 120-123: report by A. Pagenstecher "Entwurf zur Errichtung zoologisch-botanischer Stationen an deutschen Meeren".

Wachsmann, C. von, 1842. Helgoland - ein Büchlein für Lust- und Badereisende. Arnold, Leipzig, 65 pp.

\section{B) BIOGRAPHIES}

Ankel, W. E., 1958. Anton Schneider. Ein Bild und ein Nachruf. - Ber. oberhess. Ges. Nat. u. Heilk. $28,163-185$.

Ankel, W. E., 1963. Anton Schneider 1831-1890. In: Geschichte der Mikroskopie. Hrsg. von H. Freund \& A. Berg. Umschau Verl., Frankfurt a. M., 303-312.

Bautzmann, H., 1943. Johannes Müller und unsere Lehre von der organischen Gliederung und Entwicklung. - Anat. Anz. 94, 225-256.

Cohn, Ferdinand, 1901. Blätter der Erinnerung, zsgest. von seiner Gattin Pauline Cohn. Kern, Berlin, $266 \mathrm{pp}$.

Driesch, H., 1951. Lebenserinnerungen. Reinhardt, München, $311 \mathrm{pp}$.

Du Bois-Reymond, E., 1860. Gedächtnisrede auf Johannes Müller. - Abh. dt. Akad. Wiss. Berl. 1860, 25-190.

Florey, E., 1985. Historische Einleitung. In: Emil Du Bois-Reymond (1818-1896) - Anton Dohrn (1840-1909). Briefwechsel. Hrsg. von C. Groeben \& K. Hierholzer. Springer, Berlin, XV-XL.

Grobben, C., 1898. Rudolf Leuckart. Nachruf. - Verh. zool.-bot. Ges. Wien 1898, 241-243.

Haberling, W., 1922. Urkundliches über Johannes Müller und seine Vorfahren. - Z. Heimatk. Reg. Bez. Coblenz/Trier 3, 220-222.

Haberling, Wilhelm, 1924. Johannes Müller. Akad. Verl.Ges. Leipzig, 489 pp.

Haeckel, E., 1921a. Entwicklungsgeschichte einer Jugend. Briefe an die Eltern 1852-1856. Koehler, Leipzig, 216 pp.

Haeckel, Ernst, 1921b. Italienfahrt. Briefe an die Braut 1858-1860. Koehler, Leipzig, $184 \mathrm{pp}$

Heincke, F., 1899. Die Einweihung des Nordseemuseums auf Helgoland verbunden mit einer Gedächtnisfeier für Nathanael Pringsheim am 20. August 1899 - Festrede des Direktors der Biologischen Anstalt, Professor Dr. Fr. Heincke. Littmann, Oldenburg, 13 pp.

Hescheler, K., 1915. Arnöld Lang. - Vjschr. naturf. Ges. Zürich 60, 1-22.

Heuss, T., 1940. Anton Dohrn. Atlantis Verl., Heilbronn, 319 pp.

Heuss, T., 1962. Anton Dohrn. Wunderlich, Tübingen, 448 pp.

Hirsch, G. C.,1933. Die Forscherpersönlichkeit des Bioloqen Johannes Müller. - Arch. Gesch. Med. $26,166-190$.

Jahn, Ilse, 1990. Grundzüge der Biologiegeschichte. Fischer, Jena, 507 pp.

Koelliker, A., 1899. Erinnerungen aus meinem Leben. Engelmann, Leipzig, 399 pp.

Koller, G., 1958. Das Leben des Biologen Johannes Müller 1801-1858. Wiss. Verl.Ges., Stuttgart, 267 pp.

Krauße, E, 1984. Ernst Haeckel. Teubner, Leipzig, 148 pp.

Kühn, A., 1950. Anton Dohrn und die Zoologie seiner Zeit. - Pubbl. Staz. zool. Napoli (Suppl.) 1950, $1-205$.

Müller, M., 1926. Über die philosophischen Anschauungen des Naturforschers Johannes Müller. Arch. Gesch. Med. 18, 130-150.

Porep, R., 1970. Der Physiologe und Planktonforscher Victor Hensen (1835-1924) - Sein Leben und sein Werk. - Kieler Beitr. Gesch. Med. Pharm. 9, 1-147. 
Retzius, G., 1900. Briefe von Johannes Müller an Anders Retzius, von dem Jahre 1830 bis 1857. Aftonbladets, Stockholm.

Steudel, J., 1952. Wissenschaftslehre und Forschungsmethode Johannes Müllers. - Dt. med. Wschr. $77,155-118$.

Stöhr, P., 1964. Max Schultze 1825-1874. In: Geschichte der Mikroskopie. Hrsg. von H. Freund \& A. Berg. Umschau Verl., Frankfurt a. M., 367-375.

Uschmann, G., 1984. Ernst Haeckel. Prisma Verl., Gütersloh, 327 pp.

Virchow, R., 1858. Johannes Müller. Hirschwald, Berlin, $48 \mathrm{pp}$.

Wunderlich, K., 1978. Rudolf Leuckart. Fischer, Jena, 152 pp.

\section{C) ORIGINAL PUBLICATIONS}

Baker, H., 1753. Employment for the microscope. Dodsley, London, $311 \mathrm{pp}$.

Busch, W., 1847a. Einiges über Tomopteris onisciformis. - Arch. Anat. Physiol. 1847, 180-186.

Busch, W., 1847b. Ueber die Mesotrocha sexoculata. - Arch. Anat. Physiol. 1847, 187-192.

Dalla Torre, K. W. von, 1889. Die Fauna von Helgoland. - Zool. Jb. (Syst. Ökol. Geogr. Tiere) 4 (Suppl.), 1-99

Dohrn, A., 1865. Die Darwin'sche Theorie und das Experiment. - Stettin. ent. Ztg. 26, 238-241.

Dohrn, A., 1866. Zur Naturgeschichte der Caprella. - Z. wiss. Zool. 16, 245-252.

Ehrenberg, C. G., 1836. Das Leuchten des Meeres. Neue Beobachtungen nebst Übersicht der Hauptmomente der geschichtlichen Entwicklung dieses merkwürdigen Phänomens. - Abh. preuss. Akad. Wiss. 1836, 411-476.

Haeckel, E., 1855. Ueber die Eier der Scomberesoces. - Arch. Anat. Physiol. 1855, $23-31$.

Leuckart, R., 1847. Wirbeliose Thiere von Helgoland und Island. - Göttinger Nachr., 1847, 86-92.

Leuckart, R., \& Frey, H. 1847. Beiträge zur Kenntnis wirbelloser Thiere, mit besonderer Berücksichtigung der Fauna des norddeutschen Meeres. Vieweg. Braunschweig.

Leuckart, R. \& Pagenstecher, A., 1858. Untersuchungen über niedere Seethiere. - Arch. Anat. Physiol. 1858, 568-613.

Müller, J., 1846. Bericht über einige neue Thierformen der Nordsee. - Archiv. Anat. Physiol. 1846, $101-110$

Müller, J., 1847. Fortsetzung des Berichts über einige neue Thierformen der Nordsee. - Arch. Anat. Physiol, 1847, 157-179.

Müller, J., 1855. Fortsetzung der Beobachtungen über die Metamorphose der Echinodermen. Arch. Anat. Physiol. 1855, 67-89.

Müller, M., 1855a. Ueber die weitere Entwicklung von Mesotrocha sexoculata. - Arch. Anat. Physiol. 1855, 1-11.

Müller, M., 1855b. Ueber Sacconereis Helgolandica. - Arch. Anat. Physiol. 1855, 13-22.

Schneider, A., 1862. Über die Weiterentwicklung der Actinotrocha branchiata. - Mber. preuss. Akad. Wiss. 1861/1862, 934-936.

Schneider, A., 1873. Untersuchungen über Plathelminthen, - Ber. oberhess. Ges. Nat.- u. Heilk. 14, 69-140.

Schultze, M., 1851. Beobachtungen junger Exemplare von Amphioxus. - Arch. Anat. Physiol. 1851, 416-419.

Wagener, R., 1847a. Ueber eigenthümlich gestaltete Haare der Beroe und Cydippe. - Arch. Anat. Physiol, 1847, 193-194.

Wagener, R, 1847b. Ueber die Nesselfäden der Tubularien. - Arch. Anat. Physiol. 1847, $195-201$.

Wagener, R., $1847 \mathrm{c}$. Ueber den Bau der Actinotrocha branchiata. - Arch. Anat. Physiol. 1847, 202-206.

Wilms, R. F., 1846. Observationes de Sagitta mare germanicum circa insulam Helgoland incolente. Diss., Univ. Berlin. 